\title{
BACK TO THE PUBLIC? ASSESSING PUBLIC BROADCASTING IN THE NETHERLANDS JO BARDOEL
}

\begin{abstract}
New responsibility and accountability mechanisms for public broadcasters (PSB), such as the broadcast assesmentrecently introduced in the Netherlands, are meant to modernize the relationship between public broadcasters and their audiences. These new ways of organizing public broadcasting's social responsibility are a response to recent trends in broadcast policies e.g. the advent of dual broadcast systems and therefore stricter legitimation needs and competition rules for PSBs - as well as more general trends in society -

e.g. the end of stable ideologies, individualization processes and the emergence of more self-conscious citizens. Consequently the mission statements of public broadcasters have become much more explicit in recent years, and the same holds for the ways in which they accept public obligations and report about their performance in public. The tradition of political responsibility, based on explicit law and regulation but in practice often a tango of political and broadcasting elites, is now being supplemented by new forms of public accountability in which PSBs try to establish a more direct feedback with the public. The article, finally, looks at the present broadcast assessment process in the Netherlands. Based on both research evidence and personal experience of the author, questions are raised

such as: how does it work, what are the first experiences and does it seem to be a viable model for other countries? Despite risks of politicization and bureaucratization, public broadcast assessments promise to offer a useful new instrument for both internal quality control and external legitimation.
\end{abstract} Jo Bardoel is researcher at the Amsterdam School of Communications Research (ASCOR) and Professor of Media Policy at University of Nijmegen, e-mail: j.l.h.bardoel@uva.nl. 
Broadcasting in the Netherlands arose out of citizens' initiatives in civil society and was then inserted into the dominant compartmentalized socio-political system of "pillarization." This implied a hierarchical power structure but also strong involvement from the rank and file. From the 1960s, partially under the influence of internal competition between the separate public broadcasting organisations and the rise of market research in broadcasting, the citizen was treated more as a mere media consumer whose attention was fought over. Consequently, broadcasters largely lost their significance as member based associations. In the 1990s, after the arrival of the dual system, "public" broadcasters were once again forced to worry and make a claim about their raison d'être, and they decided upon a double accountability structure, for separate public broadcasters and for public broadcasting as a whole. In this article we will look at both the tradition and the new practices of public broadcasters' accountability in the Netherlands.

\section{A "Pillarized" System}

Looking in the rear-view mirror, the Netherlands neither chose for a national broadcasting system $\dot{a}$ la the $\mathrm{BBC}$, as in most other European countries, nor for a commercial broadcasting structure as in the United States or Luxembourg, but for its own solution, commonly characterised as "pillarization" (Lijphart 1975). In this system, broadcasting was not left to the state or the market, but to social movements that had already established their own organisations in most domains of social life, like politics, education, health care, culture and leisure. The broadcasting organisations within these "pillars" were not only non-commercial but also, confusingly, private associations. So, public broadcasting in the Netherlands was born out of social movement initiatives, organised privately. The radio spectrum was divided equally over the principal social groupings that operated autonomously and were financially self-supporting, thanks to an active and supportive membership. Therefore, contrary to other countries, civic participation and involvement with radio and later television has a long tradition. The broadcasting time allotted to the associations was based on the size of their membership and, to a great extent, they were free to fill this time as they chose. With interlocking directorships and ideological or religious feelings, the corporations were clearly part of the "pillar" of their own social movement. Consequently, broadcasting did not have a legitimacy problem in the first decades of its existence.

After the war, the radio corporations, and soon television too, while busy professionalizing themselves, increasingly distanced themselves from their grassroots supporters. Under the slogan of breaking the barriers of religious and sociopolitical divisions, the latter began to adopt a more relaxed attitude with regard to their own organisations and to increasingly choose from the whole range of broadcast material rather than from the programmes offered by their own organisation. This mutual process of disengagement between the broadcasting company and the public was further reinforced by the arrival of television. The "old public order" of broadcasting had difficulty grasping the public's new preferences and tastes which manifested itself in a new, more internationally-oriented youth culture, that was better understood and catered for by foreign or "offshore" commercial channels like Radio Luxembourg, and later TV-Noordzee and Radio Veronica. The Broadcasting Act of 1967 allowed TROS to enter the playing field as the legal variant of 
the "pirate" broadcasting station TV-Noordzee in the mid 1960s. As a result, fierce competition over viewer support ("popularization" which came to be known as "TROSsification") developed when the newcomer TROS introduced a more American-style, leisurely programming.

This new style of broadcasting nolonger focused on citizens but on consumers. Programmes and programming were increasingly tailored to preferences learned from market research, and the influence of democratic associations more and more became a thing of the past. In addition, the emphasis began to shift from internal competition between broadcasting corporations to external competition with foreign, increasingly commercial entrants. Ultimately, it became inevitable to allow for commercial broadcasting in the Dutch language, primarily as a result of European regulation (the Directive "Television without Frontiers"). It led to the current "dual system" in which the battle for viewers and listeners has taken on entirely new dimensions.

The rise and fall of the Dutch broadcast model thus is the result of sociological trends in society as well as structural changes in the broadcasting context. We see that bureaucratization of organisations and professionalisation of journalists gradually replaced active participation of citizens, a trend that is further reinforced in the last ten years since public broadcasting felt itself forced to co-operate and centralise in response to commercial competition. All the attempts in the past decades to reactivate citizens to participate more actively in broadcasting associations have failed, not only due to professional and organisational resistance but also because of the circumstance that people nowadays seem less easily motivated to participate actively in public organisations on a collectivist and permanent basis. New entrants into the public broadcasting system are less organised on the basis of a distinct political or religious identity and more often on a (post)modern consumerist lifestyle. As a reaction to this ongoing trend of decreasing traditional participation and representation, public broadcasting is now beginning to develop new strategies of showing responsibility or being accountable to the public, comparable to what other, national broadcasting institutions as the $\mathrm{BBC}$ are practising (Bardoel and Frissen 1999, 206).

\section{Restructuring Public Broadcasting within a European Context}

After the introduction in 1989 of a dual broadcasting structure in the Netherlands, as the result of the European Directive "Television without Frontiers," the Dutch government had to restructure and "reinvent" its broadcasting policy in the 1990s. In a first response, commercial broadcasting via cable was legalised. But Dutch politics had to redefine its position vis-à-vis public broadcasting for the long term as well. The government appointed a high level commission which advised in its report "Back to the Public" (Commissie-Ververs 1996) - to renew the social embedding of the broadcasting associations by introducing broadcasting elections as a new mechanism to allocate broadcasting time. This proposal was widely criticised because it was assumed not to cure but to worsen the disease, by increasing "consumerism" or "quasi-commercialization" of the relation between broadcasting associations and their members. There was more appreciation though for the commission's fundamental reassessment of the mission of public broadcasting as a 
provider of comprehensive, reliable, attractive and innovative programmes which function as a point of reference in an ever more complex and rapidly changing information society. The government did not follow the proposal for broadcast elections, but strongly supported the proposed mission statement. It also supported a new, more centralised management structure, including a single concession for public broadcasting as a whole, instead of many separate licences for broadcasting associations, which might revitalise the ailing public broadcasting system.

The Concession Act of 2000 represents a next step in the transformation process of public broadcasting, from a specific, national tradition towards a new European future. The memorandum to the act refers to "pluriformity" as the heritage of the Dutch broadcasting tradition and to the importance of stimulating national culture, but also to a new role public broadcasting should play, as a forum in a multicultural information society for which support from the young and from migrants is essential. Public broadcasting must guarantee pluralism, quality and distinctive programming. The tension between quality and reaching a large audience is considered inherent with public broadcasting, and should stimulate broadcasters to look for a link between high and low culture. Public broadcasting should therefore be active on both old and new platforms, such as the Internet. So-called "secondary" tasks like Internet services and thematic channels should be financed from the regular budget. Special programmes (or thematic channels) may be charged a little extra, but plain pay-TV is not allowed for public broadcasters.

Under the new act, concession holders are no longer separate associations, but it will be public broadcasting as a whole - represented by the Netherlands Public Broadcasting (NPB; the new name for that part of NOS that serves as the umbrella organisation for public broadcasting). Membership no longer decides the number of hours of broadcasting time per association. More important than membership becomes the question to what extent public broadcasters perform according to the conditions assigned by the Concession Act or to the self-assigned duties in policy plans. Every five years there will be an independent audit or assessment to check if the organisation's performance is in accordance with the promises laid down in the policy plan at the beginning of the concession period. All in all, Dutch broadcasting is in the process of moving from a decentralised system on the basis of broadcasting associations to a more centralised, $\mathrm{BBC}$-like public broadcasting structure.

The conclusion seems clear. Dutch broadcasting had a tradition of civic participation with a system that represented a third way between market freedom and state control, and that relied heavily on people's involvement. The old, pillarized society of collectives, in which stable group patterns determined living and working of people, has, however, been replaced by a (post)modern, dynamic society of individuals, in which people individually and eclectically decide how to live their own lives. Television and radio play once again a crucial role in the formation of a general "media culture" (Dahlgren 1991, 17), in which mass media have become more than political parties, churches or labour unions - the most important platforms for the formation and exchange of opinions and tastes. At the same time, people are increasingly difficult to organise on the basis of active representation and therefore this system is being replaced by a different, relatively "light touch" model of media responsibility and accountability. 


\section{Four Mechanisms of Accountability}

The issue of social responsibility and accountability of (public) broadcast media has raised considerable interest since the advent of commercial broadcasting and as a result the introduction of dual and competitive broadcasting systems in most European countries. At the core of the "old" system of public accountability were "politicians and broadcasters, to some extent each checking and balancing the other" (Blumler and Hoffmann-Riem 1992, 229). According to Sondergaard $(1996,24)$ "competition has above all forced public service media to be more responsive to the audiences than previously in the sense that viewers' and listeners' wishes and desires now carry more weight than society's desires regarding cultural or social functions. The dissolution of the monopolies meant the death of the kind of paternalism previously associated with public service media."

Both Blumler and Hoffmann-Riem (1992) and Blumler and Mitchell (1994) suggest that there is a need for a new model and for new mechanisms of social responsibility, not only because of the "new TV-regime" in Europe, but also because of a new relationship between individuals and social institutions in general. The latter refers to a broad pattern of changing social conditions such as a higher level of education and of expectations among citizens, the breakdown of traditionally authoritative institutions, an increased geographical, social and physical mobility, the decline in moral certitude, the blurring of traditional boundaries of taste and other post-modern conditions. All these trends and needs cannot be adequately tackled by the traditional dominant accountability mechanisms like the market or the state. New and extended accountability mechanisms are, according to these and other authors, also an important democratic imperative "given the formative consequences of broadcasting for popular leisure, the fabric of culture and the quality of public life."

The very concepts of responsibility and accountability imply a relationship between broadcast media and those affected by them within society. In practice there are different procedures, lines or frames of accountability for (public) broadcasters. Lange and Woldt $(1995,467)$ state that the realisation of social responsibility of television results from the interaction of several factors: (1) constitutions and laws; (2) supervision and control (licensing, etc.); (3) condition of the TV market, and (4) journalistic responsibility and self-regulation. In the same vein, McQuail (2000, 183-187) comes up with four accountability frames: (1) law and regulation; (2) the market; (3) public responsibility, and (4) professional responsibility. Both classifications share the following four mechanisms (Bardoel 2001; Bardoel and d'Haenens 2003):

1. political accountability;

2. market accountability;

3. public accountability;

4. professional accountability.

The political accountability system was - and indeed still is - dominant in public broadcasting. It comprises the legal framework for regulating the structure and functioning of broadcasting. At the same time this responsibility mechanism has its flaws, both for principal and practical reasons. In the words of Blumler and Mitchell $(1994,230)$, "the dominant political accountability mode lacks clean hands. 
The root of the problem is that politicians have vested interests in television programmes that are potentially at odds with the civic interests of viewers." Practical problems are, as McQuail $(2000,185)$ has pointed out, that formal regulation is easier to apply to structure than to content, that it is often ineffective, hard to enforce, unpredictable in its wider and long-term effects and finally inflexible and hard to change.

Market accountability is in Europe only rarely considered an adequate mechanism of social responsibility. The system of demand, supply and competition offers a good and simple indication of consumer tastes, as McQuail $(2000,185)$ rightly states. And, he adds, in the market mechanism there is no compulsion involved. At the same time, this model tends to favour majority preferences over quality of content or critical and minority voices. For public broadcasters this model may function as a useful antidote against the traditional "supply side" paternalism and, internally, as a stimulus towards more efficient behaviour. For them this mechanism is especially relevant in that advertising is a substantial source of income and thus "market shares," or in fact "audience shares," become an important parameter. In a competitive environment the pressure on public broadcasters to produce an attractive Umfelt for advertising will increase. Next to this external "commercialisation," the new competition also evokes an internal drive towards more efficiency and a quasi "internal market" (cf. BBC's "producers choice"), that some consider as yet another indicator of commercialization.

In the Dutch broadcasting situation, with private organisations within a public system, both the cultural and the commercial logic co-existed already for a long time. This mixed tradition, with many organisations, internal competition and plenty of room for advertising possibly explains why Dutch public broadcasting better than national broadcasters in neighbouring countries like Belgium and Germany - seems able to cope with commercial competition.

The professional accountability frame does relate less to the "vertical" and formal structuring of media organisations and more to the "horizontal" and often informal identification of media professionals with the standards of their own profession. Professional responsibility refers to the performance criteria and ethical codes of media professionals that often are supposed to complement to, or better: compensate for, the political or market dependency of the media organisation. The development of professional responsibility and indeed of professionalisation of media occupations is in past decades often seen as a progressive force vis-à-vis the traditional influences of the political or the market system.

According to McQuail $(2000,187)$ this professional framework is likely to work because it is voluntary, self-regulatory, non-coercive and in the self-interest of media and professionals. But it has in his view also serious limitations, since professionalism is in most cases not strongly developed within the media and as a result media professionals have "relatively little autonomy" from media management and ownership. The same holds for mechanisms of professional accountability within Dutch public broadcasting organizations. Since these associations are public and have a structure of democratic representation they consider explicit provisions that safeguard professional responsibility and accountability as obsolete. For that reason public broadcasters did not hasten to comply with a new article in the Media Act of 1988, which obliged them to have a "programme statute" that regulates editorial freedom and independence. 
Finally, public accountability has gained considerable popularity over the last decade. Although the concept and the very name of "public broadcasting" already suggest a strong emphasis on public responsibility, the reality was and is that public broadcasters rely heavily on their (exclusive) relationship with politics. "It would be a mistake," Blumler and Mitchell (1994: 221) write, "to assume that the public broadcasters have a well-developed system of accountability to their viewers. They have mainly been accountable for their goals, standards, programmes and expenditure through agencies of their political system." The overall conclusion of their inquiry is, indeed, that accountability to viewers has been marginalised and that it has so far not been a central concept in the governance of European broadcasting systems.

In trying to define "public responsibility" McQuail (2000, 186-187) indicates that most open societies display, aside from the general public opinion, a wide variety of pressure groups and lobbies that seek to look after the interest of one or other groups in society. Taken together, these many voluntary action groups are part of the informal "mechanisms" by which media are constrained to meet certain standards of performance in society. Next to this feedback mechanisms with informal but still collectively organised institutions, also the relationship with the audience becomes an ever more important part of public responsibility. With individualization being a formidable social trend, public broadcasters can no longer rely on their relationship with formal and informal groups and collectivities; they have to establish a relationship with individual, "unorganised" citizens. We see in fact that public broadcasters address their viewers and listeners more and more directly, through special broadcasts, public hearings or other more or less interactive consultation mechanisms. On the other hand more conscious citizens hold media accountable for their performance by a process of naming, blaming and claiming (Pritchard 2000). The problem with this kind of accountability procedures, however, is that they are voluntary most of the time; it is often hard to see the difference between real feedback procedures and ritual PR strategies.

\section{Shifting Social Responsibility for Public Broadcasters}

Since the mid 1980s the self-evidence of public broadcaster's legitimation has been challenged by both changing political beliefs and the introduction of commercial television in Western Europe. Public broadcasters suddenly found themselves operating in a market where also commercial stations offered their services. To counter claims of unfair competition, public broadcasters had to show more "distinctiveness" vis-à-vis commercial competitors. "As this distinction erodes, either through more light touch regulation for public broadcasters or while commercial broadcasters will show more quality, substance, cultural performance or pluralism, the power of the legitimation for public broadcasting will weaken and EU law will impose more severe restrictions on public broadcasters," warned a Dutch high level government commission in 1992 ("Commissie-Donner"; Donner et al. 1992). In this new, competitive media environment in Europe, public broadcasters

started to rethink and often rediscover their role in and social responsibility to society. Since then we notice a gradual shift from political accountability to new, public accountability mechanisms.

On the basis of a content analysis of policy documents of the public broadcasting organizations in the Netherlands over a period of 40 years Bardoel and Brants 
(2003) have traced how they have (re)defined their role in relation to the public and the public interest. Looking at the changes from the old public order (19601980), the transition period (1980-1990) and the new dual order (1990-2000), they show the ways in which public broadcasters come to terms with the more market oriented attitudes of subsequent governments and how they "translate" new regulatory frameworks in their own programme policies. They had already demonstrated that the overall awareness of social responsibility in the broadcasting policies of subsequent Dutch governments had increased over time (Bardoel, Brants and Plug 2000). This reflects both the increasing (discursive) struggle over public broadcasting in a dual and competitive system and the more critical stance of citizens and society towards the performance of social institutions and organisations in general. Emphasising more the cultural tasks is a reaction to the influx of crossborder television, the need to reposition public broadcasting vis-à-vis commercial broadcasting and, last but not least, a changing social composition of society. In a sense, it seems that in broadcast policies the old, modernist paradigm - with freedom and equality as the core values - is being replaced by a more postmodernist approach. There is more room for individual cultures, styles, and tastes and less for paternalistic policies, at least in the rhetoric. Our impression was that the specificities of Dutch broadcasting policies and their traditional legitimation erode and are being replaced by more common, perhaps "European" policy motives.

The analysis of the policy documents of the public broadcasters showed a stronger emphasis on public responsibility, on program content requirements and on the cultural tasks of public broadcasters, and particularly more attention to minorities of all kinds. References to the institutional requirements and arrangements that organized the external pluralism of the "pillarised" public broadcasting system in the Netherlands decreased in the same period in both governmental and broadcasting documents. For the broadcasters it is another indication of a shift from an internal to an external orientation of public broadcasters, and more attention for media performance in terms of content or output. It seems they are eager to follow the policy trends. Policy legitimation seems to do the same: from an implicit, via a more ritualistic to a mere strategic function for policy. This trend is also reflected in the format and content of the policy documents over time, from purely reactive vis-à-vis government policies in the old order period to much more proactive approach at present. On the basis of this, a more specific periodisation of the characteristics of social responsibility in governmental and broadcasting organizations' policy can now be sketched (see Table 1).

Table 1: Periodisation of Social Responsibility in Broadcasting Policy

\begin{tabular}{|l|c|c|c|}
\hline & $\begin{array}{c}\text { Old public order } \\
1960-1980\end{array}$ & $\begin{array}{c}\text { Transition period } \\
1980-1990\end{array}$ & $\begin{array}{c}\text { New dual order } \\
1990-2000\end{array}$ \\
\hline Government policy emphasis & Organisation & Organisation & $\begin{array}{c}\text { Organisation/ } \\
\text { Role for society }\end{array}$ \\
\hline $\begin{array}{l}\text { Broadcasters policy } \\
\text { emphasis }\end{array}$ & Organisation & $\begin{array}{c}\text { Organisation/Role } \\
\text { for society }\end{array}$ & $\begin{array}{c}\text { Content/Role for } \\
\text { society }\end{array}$ \\
\hline Policy legitimacy & Implicit & Ritualistic & Strategic \\
\hline
\end{tabular}




\section{New Accountability Mechanisms in Dutch Public Broadcasting}

The second half of the $1990 \mathrm{~s}$ is characterized by a more fundamental consideration of the future responsibilities and legitimacy of public broadcasting. A left-liberal government appointed an independent committee whose task it was to give advice on the future of public broadcasting (Commissie-Ververs 1996). In retrospect, we can see that few of the committee's practical suggestions (such as "broadcasting elections") have been put into practice, but the basic conceptualization of the significance of public broadcasting in the information society has remained.

Also based on the committee's work, the new Concession Act of 2000 represents a

paradigm shift in the perspective of the government's broadcasting policy. The main question is no longer that of who has the "right" to broadcasting time based upon membership figures and representativeness. The main question now is what Dutch society as a whole can expect. A broadcasting corporation's achieved and prospective accomplishments determine whether it will receive more broadcasting time (Van der Haak 2001, 13).

Prior to the new act, the NOS had published the memorandum Publiek in de toekomst (Public in the Future 1998), with different suggestions for new forms of "accountability." It proposed that there be a "double legitimacy" — for separate broadcasting associations and for public broadcasting as a whole — and a "double strategy" - to seek more contact with the public and to be formally scrutinized on its public function. In order to realize this, the memorandum presented a number of suggestions, the most far-reaching (following the example of higher education) being an external assessment committee periodically evaluating the extent to which public broadcasting is fulfilling its societal role. This was subsequently taken up in the Concession Act (art. 30c). In addition, public broadcasting promised to continually seek new ways of keeping in touch with society, through annual reports, debates with the public and the "creation of a television programme with an independent and mediatory character" (NOS 1998, 10).

This 'going out' to the public and being seen to be accessible and accountable was formally laid down in the Concessiebeleidsplan 2000-2010 (Strategic Plan for the Licensing Period 2000-2010; NOS 2000). Next to already existing financial and programme (quota) instruments, the plan proposed a number of new "public accountability" measures (Bardoel and d'Haenens 2002; Van Dijck 2003):

1. Accessible information:

- annual report, by programme, with balance sheet and adjustments;

- annual booklet for the general public (hard copy and electronically);

- newsletters for target groups;

2. Public dialogue:

- meetings with special interest and other organisations and target groups;

- enabling content-related group visits;

- television-mediator programme on internal operations and public reactions;

- use of the Internet for debates, publications and "meta-programmes"; 


\section{Assessment of goals:}

- a version of the financial annual report for the public;

- an assessment committee judging performance and making recommendations;

- every five years, recognition of existing broadcasters and possible admission of new broadcasters that "essentially improve the broadcasting system."

Some of these intentions are already in place (such as the annual programming report and the organisation of meetings with experts and target groups), others are still to be installed (including the mediator programme and content-related group visits). The assessment commission and periodic recognition, now statutory, is also being carried out. In addition, individual broadcasters must also demonstrate that their members "can influence policy in a verifiable and democratic manner" (NOS 2000, 11). Consequently, several broadcasting associations make considerable efforts in revitalizing and modernizing their relationship with their respective memberships.

\section{A New Performance Indicator: Assessment Commissions}

The Concession Act, as the newest version of the Media Act, obliges the Netherlands Public Broadcasting (NPB) to organise every five years an evaluation of the public broadcasters' performance. To this end, it must install an external assessment commission consisting of at least five independent experts, "as much as possible" representative for the viewing and listening audience. The commission is selected by the NPB Management Board and appointed by the Board of Governors after consultation with the minister responsible for media. The final report will be presented to the Board of Governors which will eventually publish the report. The first responsibility thus lies with the broadcasters themselves, not the government.

The Commission must, according to the new Media Act, report on the performance of both national public broadcasting as a whole and of the separate broadcasters. It must assess to what extent the programmes offered meet the "interests and insights" of the general public and of specific social and age groups in Dutch society. Article 30 leaves it to the commission to come up with recommendations on the future goals or mission of national public broadcasting and the way these should be implemented.

This periodical assessment procedure is meant to strengthen the legitimacy of public broadcasting. But it is also seen as an instrument to monitor if existing broadcasting organisations still contribute to the "dynamic plurality" of public broadcasting and that new social groupings have access to the open public broadcasting structure the Netherlands are known for. Consequently the minister for Culture will use the results of this assessment for the procedure renewing the licence of separate broadcasting organisations every five years, as part of the ten-year licence period for public broadcasting as a whole. The minister can use these results either (not) to renew the "recognition" of a broadcaster or to change the conditions under which they get a new one.

The first assessment commission, consisting of 9 members, started in January 2003 and will report before May 1,2004. The difficult combination of requirements 
has led to a commission that is in fact relatively young, fairly representative in terms of gender (apart from the chairman half of the members are women) and of ethnic background, and with no prevailing political affiliations or relations with vested broadcasting institutions. The chairman is a member of the Management Board of ING Bank who has had a career in both business and academia and is affiliated to a small left-liberal party. In its working procedures the commission closely follows the model that has proved to be practicable in higher education. Although the law does not require this, the Board of Governors of NPB has decided that broadcast organisations must first produce a so-called "self-assessment," in which all broadcasting organisations separately report on and evaluate their performance in the current concession period in relation to the plans and promises made in their strategic policy documents. In order to make these self-assessments comprehensive and comparative between organisations, the Board of Governors has designed a detailed "assessment framework" that touches upon the most relevant as pects of broadcasters performance, asking what are:

1. the programme perspective: mission and identity, performance, cooperation;

2. the audience perspective: reach, segmentation, distinctiveness, accountability;

3. the organisational perspective: structure and culture, financial transparency and efficiency, innovation.

The selection of these perspectives and the questionnaire are an adaptation of the protocol that is being used in higher education, and addresses the cultural, normative as well as financial performance criteria.

First experiences indicate that broadcasters find this self-assessment useful but difficult. They are traditionally used to defining their mission and goals in mainly qualitative and not measurable criteria and language, which makes it thus hard to evaluate one's performance in concrete and conceivable terms afterwards. Since these self-assessments present partly confidential information and organisations are invited to be self-critical, the documents will not be published. The assesment commission has started its work by reviewing the self-assessment documents of all broadcasting organisations and has continued with interviewing the management of the respective broadcasting organisations. In the first phase, the commission assesses the performance of separate broadcasting organisations that together make up the system. In the next stage it will look at the performance of public broadcasting in total, assessing the extent to which this represents the "dynamic pluralism" of (post)modern Dutch society.

\section{Positive Signs}

Although the new assessment procedure is very fresh and very much "work in progress," it is possible to give a first evaluation. Drawing on the experience in higher education and from two earlier, self-organised pilots with the new system in public broadcasting - the author was a member of these pilot commissions and is that of the present first official commission - one can conclude that this assessment procedure can become a viable instrument for both external accountability and internal quality control. The independence of the commission can give its assessments high credibility and this mechanism may therefore help to "depoliticise" the relationship between politics and public broadcasting. It thus counterbalances 
the possible effects of the recent replacement of the licence fee with taxation as the main source of revenue for public broadcasting, which was said to run the risk of too close a tango between politics and broadcasting. Public broadcasters for their part take the procedure seriously, since they know that their reputation and their "recognition" as public broadcaster may depend on it. The final assessment will be made public and may attract - as similar assessments in higher education learn - a lot of public and press attention. At the same time the analogy with higher education learns that these assessments are first and foremost meant as an incentive to stimulate organisations to critically reflect on and improve their performance, and not to terminate their existence - although this may be the ultimate step.

The self-assessment document proves to be a good start for the auditing procedure, since it stimulates the organisation to show some self-reflection and introspection and serves at the same time as a solid base for the work of the commission. Public broadcasting organisations were used to produce more or less politically correct policy documents on request, but there was no practise to regularly evaluate promises and performances. Broadcasting organisations that have experimented already with assessment procedures tend to come up with different, more measurable and concrete promises to meet for the next plan period. A certain standardization of these self-assessment documents is also a necessary precondition, since otherwise it is hard to compare the performance of the respective organisations.

At this early stage not much can be said about the work of the assessment commission itself. But drawing upon my own experience in two pilot commissions, I can say that of course the chairperson and the secretariat are crucial positions. The commission can only produce an authoritative report if it reaches consensus; to this end a competent chairperson and an open-minded, non-partisan commission with mutual trust and without hidden agendas are indispensable.

\section{Critical Notes}

All in all the assessment committee has the potential to become a valuable new policy tool, but there are also considerable risks involved. The main risks are politicization, bureaucratization and ritualisation. In some countries or cultures broadcasting is politicised to an extent that an independent commission is almost an illusion (though the same holds true for the very concept of independent public broadcasting as such). Moreover, a political system that continually comes up with new policy measures while the commission is still at work, puts pressure on its independence. The commission is then dealing most of the time with a moving target. Two new Dutch government coalitions within one year and critique on its performance in dealing with the phenomenon of the killed populist politician Fortuyn, have resulted in serious cuts in the budget of public broadcasting. In principle it were preferable if a government waits with important policy or financial measures until a concession or licensing period is over; it allows broadcasters enough time to perform according to their promises and it allows politics to act less on a haphazard basis.

As to bureaucratisation, the (self-)assessment procedure involves a lot of paper work, which might become a system and an end in itself. Moreover, it might become an additional system of control for (internal) managers and (external) super- 
visors that in fact serves as a straightjacket for the professional and creative people. On the other hand, professional broadcasters all too easily think that any kind of accountability mechanism threatens their independence, quality and creativity. Media professionals traditionally are primarily oriented towards their product and much less towards the public and their role in and for society. A feasible middle way has to be found between freedom and responsibility for public broadcasters.

Ritualisation is a risk in the same vein. Public accountability in general, and this assessment procedure in particular, may become another element in the permanent rhetorical and paper discourse between public broadcasting organisations and their political supervisors. In this discursive struggle it is never quite clear to what extent the paper reality represents and has a close relation to the "real" reality. In this context it is important that the assessment procedure remains, as originally intended, a mechanism for public accountability and not of political accountability. The specific mechanism was initially proposed by public broadcasters themselves in order to establish a new and closer relationship to citizens and civil society, and to gain independence from both the political system and commercial pressures. By putting this proposal into law, its status was certainly strengthened, but the risk of being "colonised" by the political system becomes more serious. At the same time, the mere fact that the commission was initially installed by and will finally report to the Board of Governors of Netherlands Public Broadcasting means that it still is an instrument of self-regulation and of public accountability.

\section{Conclusion}

Direct access of social movements to radio and television and a public broadcasting system based on separate associations with ideologically or religiously organised members has created in the Netherlands a diversity of content and an involvement of citizens hardly known anywhere else in the world. At the same time we see that sociological developments and changes in the broadcasting context have outdated the system and called for structural reform. These changes only came slowly and incrementally, and it was finally not national politics but "Brussels" that paved the way for a dual broadcasting system. "Public accountability" has been dominant during the old order of pillarized public broadcasting. The erosion of the pillar system allowed for more autonomy of the professionals and resulted in both political and professional accountability. Moreover, the Broadcasting Act of 1969 had also introduced a quasi-commercial competition, and thus a kind of market accountability. This mechanism became even stronger in the 1980s when a combination of stagnating income and increasing programme output made more efficiency imperative. Recently, with dual competitive broadcasting putting pressure on the legitimacy of and political commitment for the public structure, we notice a renewed interest for public responsibility. However, it is no longer embedded in a national tradition of emancipating the audiences and supporters of separate pillars, but in a new, more European perception of public broadcasting. New accountability mechanisms for public broadcasting as a whole have been created along with an assessment procedure, which is conditional for holding or obtaining a licence.

Although vague and sometimes disputed, social responsibility and accountability are still pretentious notions. Their actuality coincides with important social 
trends: the shift in policy approach from looking at organisational structure to emphasising informational and cultural performance; the emergence of a more conscious, critical and even cynical citizen; and the emphasis on "good governance" as an important trend within government and the business community. The public has gradually evolved into a media consumer, a process both witnessed and strengthened by audience research. A greater involvement of citizens in media matters may offer an answer to these issues.

The new mechanisms of public accountability in the Netherlands look promising. The newly introduced periodical assessment procedure by way of an independent commission, as part of the licence renewal process, can become a valuable instrument for external accountability and internal quality control. It may also serve to depoliticise the relationship between politics and public broadcasting, especially since the licence fee has been replaced by taxation. It remains, however, to be seen whether this new instrument can overcome the inherent risks of politicization and bureaucratization and whether the outcome becomes part of symbolic politics or will be indeed symptomatic for a new and "listening" public broadcasting system.

\section{References:}

Bardoel, Jo. 2001. Open Media, Open Society. Rise and Fall of the Dutch Broadcast Model: A Case Study. In Y.N. Zassourski and E. Vartanova (eds.). Media for the Open Society, 98-121. Moscow: Faculty of Journalism).

Bardoel, Jo and Valerie Frissen. 1999. Policing Participation: New Forms of Participation and Citizenship and their Implications for a Social Communications Policy. Communications \& Strategies 34, 203-228.

Bardoel, Jo and Kees Brants. 2003. From Ritual to Reality. Public Broadcasters and Social Responsibility in the Netherlands. In G. Lowe and T. Hujanen (eds.). Broadcasting and Convergence: New Articulations of the Public Service Remit, 167-187. Goteborg: NORDICOM.

Bardoel, Jo, Kees Brants, and Rene Plug. 2000. Responsible and Accountable. Broadcasting Policy between Public Obligation and Private Needs, in: J. van Cuilenburg and R. van der Wurff (eds.). Media \& Open Societies: Cultural, Economic and Policy Foundations for Media Openness and Diversity in East and West, 80-104. Amsterdam: Het Spinhuis.

Bardoel, Jo and Leen d'Haenens. 2003. Media en maatschappelijke verantwoordelijkheid; van theorie naar praktijk (Media and Social Responsibility; from Theory to Practice). In Raad voor Maatschappelijke Ontwikkeling (ed.). Medialogica. Over het krachtenveld tussen burgers, media en politiek. Advies 26. (Media Logic. About the dynamic relationship between citizens. media and politics). 99-151 Den Haag: Sdu Uitgevers.

Blumler, Jay G. and Wolfgang Hoffmann-Riem. 1992. Toward Renewed Public Accountability in Broadcasting. In J. G. Blumler (ed.). Television and the Public Interest. Vuinerable Values in West European Broadcasting. 218-228. London: Sage.

Blumler, Jay G. and Jeremy Mitchell. 1994. In Conclusion: Beyond State and the Market. In J. Mitchell and J.G. Blumler (eds.). Television and the Viewer Interest. Exploration in the Responsiviness of European Broadcasters, 227-241. London: Libbey.

Commissie-Ververs. 1996. Terug naar het publiek (Back to the Public). Den Haag: KPMG Management Consulting.

Dahlgren, Peter. 1991. Introduction. In P. Dahlgren and C. Sparks (eds.). Communication and Citizenship. Journalism and the Public Sphere in the New Media. 1-24. New York: Routledge.

Donner, Piet Hein, J. M. de Meij, and K.J.M. Mortelmans. 1992. Verdeelde frequenties, veranderde omroep: advies van de Commissie Etherfrequenties en Commerciele Omroep (Distributed frequencies, a changed broadcasting context: advice by the Commission for Ether Frequencies and Commercial Broadcasting). Rijswijk: Ministerie van Welzijn, Volksgezondheid en Cultuur.

European Commission. 1989. Television without Frontiers. EC/89/552. PbEG 1989, L 298/23. 
Lange, Bernd-Peter and Runar Woldt. 1995. The Results and Main Conclusions of the International Comparison. In J. Dries and R. Woldt (eds.). The Role of Public Service Broadcasting in the Information Society, 463-503. Düsseldorf: European Institute for the Media.

Lijphart, Arend. 1975. The Politics of Accommodation: Pluralism and Democracy in the Netherlands. 2nd edition. Berkeley: University of California Press.

McQuail, Denis. 2000. McQuall's Mass Communication Theory. 4th edition. London: Sage.

Mitchell. Jeremy and Jay.G. Blumler. 1994. Television and the Viewer Interest. Exploration in the Responsiveness of European Broadcasters. London: Libbey.

NOS. 1998. Publiek in de toekomst (Public in the Future). Hilversum: NOS.

NOS. 2000. Verschil maken: Concessiebeleidsplan landelijke publieke omroep 2000-2010 (Making a Difference. Public Broadcasting Policy Plan for the Licensing Period 2000-2010). Hilversum: NOS.

Pritchard, David. 2000. Holding the Media Accountable. Citizens, Ethics and the Law. Bloomington: Indiana University Press.

Sondergaard, Henrik. 1996. Public Service after the Crisis. Nordicom Review 1. 107-120.

Staatssecretaris van OCIW. 1997. Wijziging van de mediawet in verband met de invoering van een vernieuwd concessiestelsel voor de landelijke publieke omroep. ("Concessiewet") Memorie van Toelichting (Amendments to the Media Act in relation to a new licensing system for national public broadcasting /"Concession Act"/. Explanatory Memorandum). Den Haag: Tweede Kamer, 98-99, 25 660, 3,1-26.

Van Dijck. Bernadette. 2003. Accountability in Practice. Lecture at the Expert Meeting on Media in Dynamic Interaction with Government, Market and Citizens, University of Antwerp. March 28.

Van der Haak, Kees. 2001. Publieke omroep straks afgerekend op prestaties (Public Broadcasting held accountable for its performance). Informatie \& Informatiebeleid 19, 3, 10-17. 